\title{
Analysis of Organic Compounds: Applications in Archaeology and Earth Science
}

\section{Oliwia Grafka1', Dagmara H. Werra², Rafał Siuda}

\section{Abstract}

Kivonat
Analysis of molecular composition of organic matter in lithics can determine correlations between organic matter and rock source. The paper presents the possibilities and limitations of using this method in Earth Sciences and Archaeology.

\section{Szerves alkotóelemek vizsgálata: régészeti és földtudományi alkalmazások}

A kőzetekben található szerves anyagok molekuláris összetétele árulkodó lehet a kőzet eredetének helyét illetően. E cikkben bemutatjuk ezen elemző módszer felhasználásának lehetőségeit és korlátait a földtudományokban és a régészetben.

Keywords

Flint, Analyses of molecular composition of organic compounds, Archaeology, Earth science

Kulcsszavak

kova, szerves alkotóelemek molekuláris összetételének analízise, régészet, földtudomány
1 - Warsaw University, Faculty of Geology, Institute of Geochemistry, Mineralogy and Petrology, Żwirki i Wigury 93, 02-089 Warszawa, Poland. oliwia.grafka@uw.edu.pl; rsiuda@uw.edu.pl

2 - Autonomous Research Laboratory for Prehistoric Flint Mining, The Institute of Archaeology and Ethnology Polish Academy of Sciences, Aleja Solidarności 105, 00-140 Warszawa, Poland. werra@iaepan.edu.pl

Cite as / Hivatkozás

Grafka, O., Werra, D.H., Siuda, R. (2015) Analysis of Organic Compounds: Applications in Archaeology and Earth Science Litikum 3: 27-38. https://doi.org/10.23898/litikuma0010

Received // Érkezés: 2015. 08 . 25. Accepted // Elfogadás: 2015. 11. 25. Published // Közzététel: 2016. 02. 02.

Article history / Kézirat történet

Copyright / Jogok

()๑) (c) 2015 Grafka, Werra, Siuda. Ez egy nyílt hozzáférésű publikáció, amit a Creative Commons 4.0 licensze véd. A termék szabadon használható, terjeszthető és sokszorosítható az eredeti szerző és forrás megjelölése mellett. // This is an open-access article distributed under the terms of the Creative Commons Attribution License, which permits unrestricted use, distribution, and reproduction in any medium, provided the original author and source are credited.

\section{Introduction}

The majority of tools used by prehistoric communities were made of stone, a material that provided implements with sharp and durable edges. The most suitable type of stone needed to be hard and with a homogeneous structure, for instance obsidian (volcanic glass). But deposits of obsidian were not easy to come by, so early communities turned their attention towards flint, another high-quality raw material commonly occurring in Europe, which became the prime material for tool production in prehistoric times.

When studying prehistoric flint, one of the most interesting issues to be examined is the connection between deposits exploited at the time and the tools recorded at archaeological sites. By following the spread and distribution of particular raw materials we can study the spreading of prehistoric communities, their mobility and mutual contacts, as well as the size and quality of exchange networks.
At the same time, those features which caused siliceous rocks to be highly prized by ancient communities also mean that it is extremely difficult to link a deposit to concrete artefacts found at an archaeological site. That is why researchers try to describe the diagnostic features of siliceous rocks using various petrographic and geochemical methods (e.g. Sieveking et al. 1972; Sieveking, Hart 1986; Sieveking, Newcomer 1987; Schild, Sulgostowska 1997; Allard et al. 2008; Přichystal 2009, 2013; in Poland: Schild 1971; Lech 1980; Michniak 1980; Budziszewski, Michniak 1989; KamińskaSzymczak, Szymczak 2002; Krajcarz, Krajcarz 2009).

One of the new methods recently introduced to archaeology is analysis of the molecular composition of organic compounds in flint. The method is commonly used in geology and serves to determine the source of the organic matter and its degree of transformation, both thermal and resulting from secondary processes such as its later oxidation or decomposition by microorganisms. It is also applied for correlation between liquid hydrocarbons (crude oil) and 
the source rock from which the hydrocarbon originates. The method's success in the case of hydrocarbons, encouraged archaeologists to try it out on flint, in order to connect the flint used to produce tools to the deposit from which it was extracted. The determined organic matter comes from transformation of the mainly soft tissue of organisms that died and were deposited at the bottom of a body of water. The organic compounds of which the organisms were built underwent a series of geochemical transformations, providing hydrocarbons which could be extracted and determined analytically (e.g. Peters et al. 2005; Killops, Killops 2005).

\section{Description of the method}

The preparation of the sample is time consuming. The first stage entails selecting a piece of rock of appropriate weight. In the case of flint, which has a low organic carbon content, this means about $300 \mathrm{~g}$. The flint is then washed in running water and cleaned mechanically (using an iron brush) to remove all impurities. Finally, the material must be cleaned further, using an organic solvent such as acetone or methanol, in order to remove any contamination by petroleum compounds (very common in the environment today). Also, the rock sample cannot be weathered. The next stage involves grinding the sample to a powder (c. $20 \mu \mathrm{m}$ in diameter). The powder is placed in cellulose thimbles and undergoes extraction with organic solvents (in our case: dichloromethane and methanol in a ratio of 97:3).

The extraction process, in a Soxhlet extractor lasts about 72 hours for a single sample. The obtained extract is then separated, for instance using a modified chromatography column (Bastow et al. 2007), into three principal fractions: aliphatic, aromatic and polar.

During further stages only the aliphatic and aromatic fractions are used. These are analyzed in a gas chromatograph coupled with a mass spectrometer (GC-MS, in the case of the below mentioned grant a Perkin Elmer Clarus 500). This is done to identify determinable organic compounds. The analysis is carried out using a capillary column (Elite - 5MS $30 \times 0.25 \mathrm{~mm}$, diameter $0.25 \mu \mathrm{m}$ ), where the carrier gas is helium.

For the aliphatic fraction in the gas chromatograph (GC) the following programme is used for the oven: initial temperature of $40^{\circ} \mathrm{C}$ is held for one minute and then rises by $20^{\circ} \mathrm{C} / \mathrm{min}$ to $120^{\circ} \mathrm{C}$. The temperature then rises by $3^{\circ} \mathrm{C} / \mathrm{min}$ to $300^{\circ} \mathrm{C}$. The final temperature is held for 30 minutes. The complete programme time is 95 minutes.

For the aromatic fraction the following GC programme was used : initial temperature of $40^{\circ} \mathrm{C}$ held for $2 \mathrm{~min}$. In the next phase the temperature increased by $10{ }^{\circ} \mathrm{C} / \mathrm{min}$ to 120 ${ }^{\circ} \mathrm{C}$ and then $4{ }^{\circ} \mathrm{C} / \mathrm{min}$ until reaching $300{ }^{\circ} \mathrm{C}$. The final temperature was held for $35 \mathrm{~min}$. Complete time of analysis was $90 \mathrm{~min}$. The mass spectrometer worked in the weight range 45-550 Da.

\section{Applications in Archaeology and Earth Science}

Analysis of the molecular composition of organic matter has been successfully used in geology since the 1960s.

In order to identify the source of the organic matter dispersed in rocks and the transformations it underwent due to temperature changes (being driven deep into the earth), or weathering of rocks, the common approach is to interpret the distribution of whole groups of organic compounds or the presence of single hydrocarbons, so-called biomarkers. For instance, it is thought that when compounds with an odd number of carbon atoms in the molecule dominate among $n$-alkanes with long hydrocarbon chains $\left(n-\mathrm{C}_{25}{ }^{-}\right.$ $n-C_{31}$ ) it would suggest the input of land plants in the organic matter, but this feature gradually disappears with the increased degree of thermal transformation of rocks (e.g. Killops, Killops 2005; Peters et al. 2005).

Biomarkers are organic compounds present in extractable organic matter which indisputably indicate a connection with biological precursors, in spite of the changes they were subject to during, among other things, diagenesis. Owing to the diversity of compounds, biomarkers can often be linked to a concrete group of plants, animals or bacteria from which they originate. Biomarkers are very useful in following the 'geohistory' of oil, its origin and maturation. Complex molecules such as 4 and 5 ring cyclic isoprenoids, i.e. steranes and hopanes, provide the most information.

For instance diterpenoids, cyclic isoprenoids composed of four isoprene units, come from compounds identified in resins of vascular plants, especially resins of conifers. Examples of compounds from this group are norpimarane, labdane, fichtelite, pimarane, isopimarane, abietane or the kaurene group.

A high concentration of fichtelite in the extracted organic matter, together with the presence of abietanes, is considered to indicate the presence in the extract of organic matter originating from the pine family (Pinaceae), while extracts containing phenol derivatives of abietanes are thought to indicate a predominance of the cypress family (Cupressaceae). In turn, derivates of, among others, $\beta$-amiryn, $\alpha$-amiryn, friedelin and lupeol are considered biomarkers of angiosperms (Fabiańska 2007).

Geology uses not only individual biomarkers but also diagrams which take into account the relative concentration of concrete hydrocarbons, also biomarkers. Calculation parameters and diagrams proposed by Marynowski et al. (2000), worked well when the authors analyzed organic matter from the Devonian carbonate rocks of the Holy Cross (Świętokrzyskie) Mountains, as well as from Sylurian siliceous rocks (hornstones, shales and cherts) from the Bardzkie Mountains (Sudetes). One example of such an interpretation is presented in Fig. 1 (Grafka 2013).

The presence and relationship between relative concentrations of organic compounds provides information about 


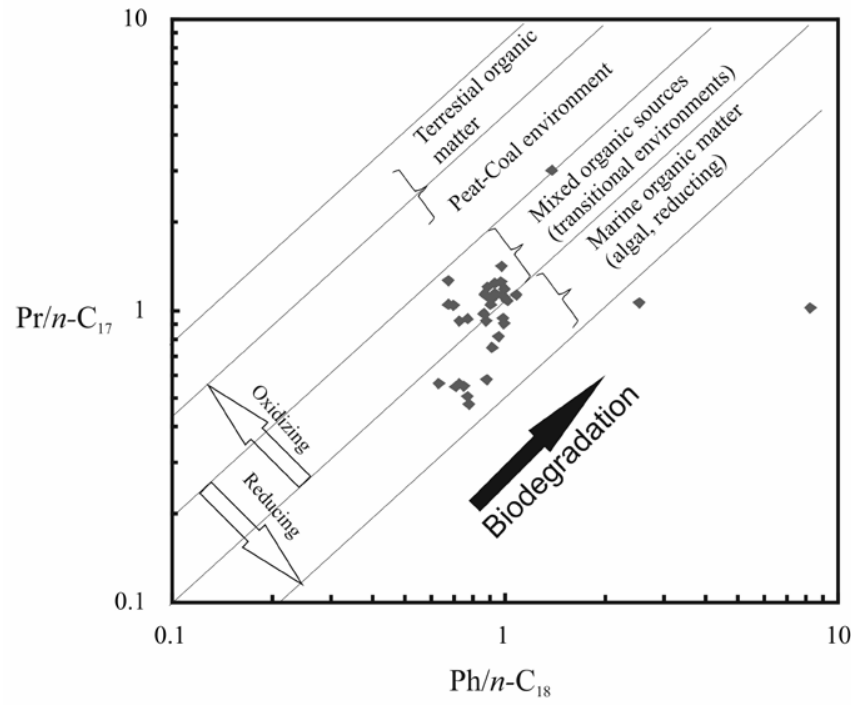

Figure 1. Diagram showing relationship between content of linear isoprenoids of pristane (Pr) and phytane (Ph) and $n$-alkanes with $17(n$ $\left.C_{17}\right)$ and $18\left(n-C_{18}\right)$ carbon atoms in chain. From this we can surmise that the organic matter from outcrops of Early Palaeozoic rocks in Żdanów (Bardzkie Mts.) is of marine origin, mainly algae and was deposited in an oxygen-poor environment (Grafka 2013). //

1. ábra. A prisztán $(\mathrm{Pr})$ és fitán $(\mathrm{Ph})$ lineáris izoprenoid tartalom, valamint a $17\left(n-C_{17}\right)$ és $18\left(n-C_{18}\right)$ atomos szénláncú $n$-alkán tartalom közötti összefüggést mutató diagram. Ez alapján feltételezhető, hogy Żdanów (Bardzkie-hg.) korai paleozóikumból származó kőzeteinek szerves öszszetevői tengeri eredetűek, főleg algák, melyek oxigénszegény környezetben rakódtak le (Grafka 2013).

the environmental conditions in which the sediments were deposited. Geologists are very interested in rocks which were formed when a body of water suffered oxygen depletion or in euxinic conditions. A well-documented event of this kind in the Late Devonian formations from the Holy Cross Mountains has been described by Marynowski and Filipiak (2007) and Marynowski et al. (2010), and by others elsewhere, for instance in the USA the Devonian-Carboniferous black shale (Brown, Kenig 2004) or in cores drilled in the ocean floor (van Bentum et al. 2012).

Hydrocarbons have also served to determine naturally caused fires in Earth's past (e.g. Marynowski, Simoneit 2009) and, in consequence, have made possible interpretations of climate (e.g. Jiang et al. 1998).

A separate issue is changes taking place in organic compounds when rocks heat up as they sink down into the earth's crust. The changes, often called maturity of organic matter, are connected with the generation of liquid hydrocarbons (thermally mature organic matter). In geology a number of maturity indicators are used based on the relative concentrations of compounds from various groups (e.g. Hunt 1996; Killops, Killops 2005; Peters et al. 2005).

Organic matter in rock is also affected by weathering, biodegradation or water washout. These factors lead to gradual depletion and, finally, complete removal of organic matter from the rock (e.g. Marynowski et al. 2011; Fischer, Gaupp 2005; Sinninghe Damsté et al. 2002; Bastow et al. 2007).
In the more general works of Hunt (1996), Killops and Killops (2005), Peters et al. (2005) or Fabiańska (2007) and in articles such as Greenwood et al. (2006), we can find more detailed information concerning the method discussed here.

The methods proposed by researchers in organic geochemistry can also be applied in archaeology. Such work has been done, for instance, by Krajcarz et al. (2013), or in the earlier mentioned research project whose objective is to describe varieties of chocolate flint (Fig. 2; Fig. 3; Table 1).

In the analyzed samples of flint, the main carriers of organic matter are hydrocarbons of polar fraction which represent the heaviest compounds (Fig. 3; Table 1). Their considerable share shows that the organic matter which occurs in flint has undergone great transformations connected with secondary processes (weathering, biodegradation, water washing). These processes have led to removal of lighter organic compounds and concentration of heavier hydrocarbons (e.g. Peters et al. 2005; Killops, Killops 2005; Marynowski et al. 2011).

On the complete chromatogram of the aliphatic fraction (saturated) the elevated background (marked as UCM; see Fig. 4) is clearly visible, evidence of the presence of an unresolved compound mixture. The presence of this mixture is one of the indications that the analyzed material is biodegraded (e.g. Peters et al. 2005; Killops, Killops 2005).

Important components of the aliphatic fraction are $n$-alkanes (Fig. 5). Their distribution begins with a hydrocarbon of 16 atoms in chain $\left(n-C_{16}\right)$ and takes on a monomodal character. The maximum of relative concentration was found in compounds with short hydrocarbon chains. Within hydrocarbons of long chains there was a dominance of compounds with odd numbers of carbon atoms in a chain.

The next analyzed group of compounds within the aliphatic fraction is tri- and pentacyclic triterpenoids (Fig. 6; Table $2,3)$. All samples of the examined flint are characterized by similar distribution within that group. This indicates that the organic matter present in the flint came from a similar source and underwent similar diagenetic processes. The extracts also contained tricyclic triterpenes. The presence of this group is a good prognostic for investigations of correlations between particular occurrences of flint. This group is applied for correlations between crude oil and source rocks (e.g. Killops, Killops 2005; Peters et al. 2005).

Organic compounds from the sterane group also occurred in all analyzed samples and their distribution was similar in each of the analyzed extracts. Additionally, the presence of diasteranes was determined (low retention time; see Fig. 7). These types of diasteranes indicate the presence of clay minerals during the transformation of organic matter (e.g. Peters et al. 2005).

The most distinct differences appear within the distribution of tri- and pentacyclic triterpenoids. The most visible variations were present between samples from the 
Wierzbica "Zele" flint mine and from the quarry in Błaziny Górne (Fig. 6B). In the extracts from "Zele", the compound of relatively highest concentration was $\mathrm{C}_{23}$ tricyclic triterpene, while in the extract from Błaziny Górne $C_{30} \alpha \beta$ pentacyclic triterpene. In this extract, the presence of hopanes with the $\beta \alpha$ configuration was determined. The extracts from "Zele" did not contain this compound group. The difference probably results from the lower thermal maturity of the organic matter in the Błaziny Górne flint and/or from lesser influence of secondary processes (e.g. Peters et al. 2005).

The project aims to differentiate between flint materials from various localities. Should the results of analyses be positive, the method could serve in future to determine correlations between flint artefacts and prehistoric mines. However, it must be taken into account that in order to acquire an extract of organic matter dissolvable in solvents, the sample has to be ground before it can undergo extraction.

\section{Conclusion}

This analysis provides the molecular composition of aliphatic and aromatic fractions. On the basis of thus identified organic compounds, it is possible to determine the original environment of the organic matter (e.g. plant, algal, planktonic, etc.), the environment in which sedimentation of organic matter occurred (e.g. open sea, shelf, delta, lake) or the conditions during sedimentation (e.g. aerobic, anaerobic, euxinic). The method also makes it possible to determine the conditions prevailing in the sediment after the organic matter had been deposited (aerobic, anaerobic) and secondary transformations of organic matter (biodegradation, water washout, weathering). Analysis of molecular composition of organic matter can determine correlations between oil and source rock, and could possibly be used to determine correlations between prehistoric flint artefacts and specific prehistoric mines.

\section{Acknowledgement}

The method was first applied to study flint as part of the research project "Diversity of Upper Jurassic 'chocolate' flint from the central Poland from the standpoint of being able to identify them in the archaeological research", project financed from funds provided by the National Science Center - PRELUDIUM 2 DEC-2011/03/N/HS3/03973.

\section{References}

Allard, P., Bostyn, F., Gilignay, F., Lech, J. (eds.) 2008. Flint mining in prehistoric Europe: interpreting the archaeological records. BAR International Series 1891, Oxford: Archaeopress.

Balcer, B. 1976. Position and stratigraphy of flint deposits, development of exploitation and importance of the świeciechów flint in prehistory. Acta Archaeologica Carpathica 16: 179-199.

Bastow, T. P., van Aarssen, B. G. K., Lang, D. 2007. Rapid smallscale separation of saturate, aromatic and polar components in petroleum. Organic Geochemistry 38: 1235-1250. https://doi. org/10.1016/j.orggeochem.2007.03.004

Brown, T. C., Kenig, F. 2004. Water column structure during deposition of Middle Devonian-Lower Mississippian black and green/gray shales of the Illinois and Michigan Basins: a biomarker approach. Paleogeography, Paleoclimatology, Paleoecology 215: 59-85. https://doi.org/10.1016/S0031-0182(04)00452-3

Budziszewski, J. 2008. Stan badań nad występowaniem i pradziejową eksploatacją krzemieni czekoladowych. In: Borkowski, W., Libera, J., Sałacińska, B., Sałaciński, S. (red.), Krzemień czekoladowy w pradziejach. Materiały z konferencji w Orońsku 08-10.10.2003. Studia nad gospodarka surowcami krzemiennymi w Pradziejach 7, Warszawa-Lublin: Państwowe Muzeum Archeologiczne, Instytut Archeologii UMCS, 33-106.

Budziszewski, J., Michniak, R. 1989. Z badań nad występowaniem, petrograficzną naturą oraz prahistoryczną eksploatacją krzemieni pasiatych w południowym skrzydle niecki MagońFolwarczysko. Wiadomości Archeologiczne 49/2: 151-190.

Budziszewski, J., Grużdź, W., Jakubczak, M., Szubski, M. 2015. Chalcolithic raw material economy in light of new data from the „Przyjaźń” mining field in Rzeczkowo (Central Poland). In: Mangado, X., Crandell, O., Sánchez, M., Cubero, M. (eds.), International Symposium on Knappable Materials „On the Rocks”, 7-11 September 2015, Barcelona, Abstracts, Barcelona: Universitat de Barcelona, 56.

Dadlez, R., Marek, S., Pokarski, J. (eds.) 2000. Mapa geologiczna Polski bez utworów kenozoiku, skala 1:1000 000. Warszawa.

Fabiańska, M. 2007. Geochemia organiczna węli brunatnych wybranych złóż Polski. Katowice: Wydawnictwo Uniwersytetu Śląskiego.

Fischer, C., Gaupp, R. 2005. Change of black shale organic material surface during oxidative weathering: implication for rockwater surface evolution. Geochemica et Cosmochimica 69: 12131224. https://doi.org/10.1016/j.gca.2004.09.021

Grafka, O. 2013. Ewolucja materii organicznej drobnoziarnistych utworów staropaleozoicznych Gór Bardzkich (Sudety). Doctoral thesis, University of Warsaw, Warsaw.

Greenwood, P. F., Leenheer, J. A. McIntyre, C., Berwick, L., Franzmann, P. D. 2006. Bacterial biomarkers thermally released from dissolved organic matter. Organic Geochemistry 37: 597609. https://doi.org/10.1016/j.orggeochem.2005.12.009

Hunt, J. M. 1996. Petroleum geochemistry and geology. New York: W. H. Freeman and Company.

Jiang, C., Alexander, R., Kagi, R. I., Murray, A. P. 1998. Policyclic aromatic hydrocarbons in ancient sediments and their relationship to paleoclimate. Organic Geochemistry 29: 1721-1735. https://doi.org/10.1016/S0146-6380(98)00083-7

Kamińska-Szymczak, J., Szymczak, K. 2002. Powierzchnie świeżych przełamów wybranych surowców krzemiennych z terenów Polski obserwowanych przy użyciu SEM. In: Matraszek, B., Sałaciński, S. (red.), Krzemień świeciechowski w pradziejach. Materiaty $z$ konferencji $w$ Ryni, 22-24.05.2000. Studia nad gospodarką surowcami krzemiennymi w Pradziejach 4, Warszawa: Semper, 297-306.

Killops, S., Killops, V. 2005. Introduction to Organic Geochemistry. 2nd edition. Cornwall: Blackwell Publishing. https://doi. org/10.1002/9781118697214

Krajcarz, M. T., Krajcarz, M. 2009. The Outcrops of Jurassic Flint Raw Materials from South-western Margin of the Holy Cross Mountains. Acta Archaeologica Carpathica 44: 183-195.

Krajcarz, M. T., Cyrek, K., Gola, M. 2013. Osadnictwo paleolityczne w 
jaskini Biśnik w zapisie antropogenicznych biomarkerów. Prace i Studia Geograficzne 51: 57-68.

Lech, J. 1980. Geologia krzemienia jurajskiego-podkrakowskiego na tle innych skał krzemionkowych. Wprowadzenie do badań z perspektywy archeologicznej. Acta Archaeologica Carpathica 20: 163-228.

Marynowski, L., Filipiak, P. 2007. Water column euxinia and wildfire evidence during deposition of the Upper Famennian Hangenberg event horizon from Holy Cross Mountains (central Poland). Geological Magazine 144: 569-595. https://doi. org/10.1017/S0016756807003317

Marynowski, L., Simoneit, B. R. T. 2009. Widespread upper Triassic to Lower Jurassic wildfire records from Poland: evidence from charcoal and polycyclic aromatic hydrocarbons. Palaios 24: 785798. https://doi.org/10.2110/palo.2009.p09-044r

Marynowski, L., Narkiewicz, M., Grelowski, C. 2000. Biomarkers an environmental indicators in carbonate complex, example from the Middle to Upper Devonian Holy Cross Mountains. Sedimentary Geology 137: 187-212. https://doi.org/10.1016/ S0037-0738(00)00157-3

Marynowski, L., Filipiak, P., Zatoń, M. 2010. Geochemical and palynological study of the Upper Famennian Dasberg event horizon from the Holy Cross Mountains (central Poland). Geochemisty Magazine 147: 527-550. https://doi.org/10.1017/ S0016756809990835

Marynowski, L., Kurkiewicz, S., Rakociński, M., Simoneit, B. R. T. 2011. Effects of weathering on organic matter: I. Changes in molecular composition of extractable organic compounds caused by paleoweathering of Lower Carboniferous (Tournaisian) maine black shale. Chemical Geology 285: 144-156. https://doi. org/10.1016/j.chemgeo.2011.04.001

Michniak, R. 1980. Petrograficzia i geneza ciemnych krzemieni z dolnoturońskich osadów okolic Ożarowa nad środkową Wisłą. Archiwum Mineralogiczne 36: 83-106.

Peters, K. E., Walters, C. C., Moldowan, J. M. 2005. The Biomarker Guide. Vol. 2: Biomarkers and Isotopes in Petroleum System and Earth History. Cambridge: Cambridge University Press.

Přichystal, A. 2009. Kamenné suroviny v pravěku východní části střední Evropy. Brno: Masarykova univerzity.

Přichystal, A. 2013. Lithic raw materials in prehistoric times of eastern Central Europe. Brno: Masarykova univerzity.

Schild, R. 1971. Lokalizacja prahistorycznych punktów eksploatacji krzemienia czekoladowego na północnowschodnim obrzeżeniu Gór Świętokrzyskich. Folia Quaternaria 39: 1-61.

Schild, R. 1976. Flint mining and trade in polish prehistory as seen from the perspective of chocolate flint of central Poland. A second approach. Acta Archaeologica Carpathica 16: 147-177.

Schild, R., Sulgostowska, Z. (eds.) 1997. Man and flint. Proceedings of the VIIth International Flint Symposium. Warszawa: Institute of Archaeology and Ethnology, Polish Academy of Sciences Warsaw.

Sieveking, G. de G., Hart, M. B. (eds.) 1986. The scientific study of flint and chert. Cambridge: Cambridge University Press.

Sieveking, G. de G., Newcomer, M. H. (eds.) 1987. The human uses of flint and chert. Cambridge: Cambridge University Press.

Sieveking, G. de G., Bush, P., Ferguson, J., Craddock, P. T., Hughes, M. J., Cowell, M. R. 1972. Prehistoric flint mines and their identification as sources of raw material. Archaeometry 14: 15176. https://doi.org/10.1111/j.1475-4754.1972.tb00061.x

Sinninghe Damsté, J. S., Rijpstra, W. I. C., Reichart, G.-J. 2002. The influnece of oxic degradation on the sedimentary biomarker record II. Evidence from Arabian Sea sediments. Geochemica et Cosmochemica 66: 2737-2754. https://doi.org/10.1016/ S0016-7037(02)00865-7

van Bentum, E. C., Richart, G. J., Sinninghe Damsté, J. S. 2012. Organic matter provenance, paleoproductivity and bottom water anoxia during the Cenomanian/Turonian Oceanic Anoxic event in the Newfounland Basin (Northern proto North Atlantic Ocean). Organic Geochemistry 50: 11-18. https://doi.org/10.1016/j. orggeochem.2012.05.013

\section{SKAM 2014 Article}

This study was presented at the 11th SKAM Lithic Workshop: the multifaceted biface - Bifacial technology in Prehistory. 20th-22nd of October, 2014, Miskolc, Hungary.

The conference papers are published in the Litikum Journal volumes as special contributions. Informations about the conference as well as the abstract book are available on the SKAM 2014 website: http://skam.pannontenger.hu 


\begin{tabular}{|c|c|c|c|c|c|}
\hline site & $\begin{array}{l}\text { type of flint } \\
\text { (archaeological } \\
\text { name) }\end{array}$ & $\begin{array}{l}\text { symbol of the } \\
\text { sample }\end{array}$ & aliphatic & aromatic & polar \\
\hline Wierzbica "Zele", Radom District & "chocolate flint" & WZS-28 & 18.18 & 2.27 & 79.55 \\
\hline Wierzbica "Zele", Radom District & "chocolate flint" & WZr81-1 & 22.78 & 6.33 & 70.89 \\
\hline Wierzbica "Zele", Radom District & "chocolate flint" & WZ1B & 0.58 & 0.10 & 99.33 \\
\hline Wierzbica "Zele", Radom District & "chocolate flint" & WZ2B & 9.89 & 6.59 & 83.52 \\
\hline Wierzbica "Zele", Radom District & "chocolate flint" & WZ3B & 0.00 & 100.00 & 0.00 \\
\hline Wierzbica - outcrop, Radom District & "chocolate flint" & WIK1 & 2.38 & 7.14 & 90.48 \\
\hline Orońsko, Szydłowiec District & "chocolate flint" & ORO1 & 15.91 & 3.41 & 80.68 \\
\hline Orońsko, Szydłowiec District & "chocolate flint" & ORO2 & 48.06 & 26.60 & 25.35 \\
\hline Orońsko "Mały Orońsk", Szydłowiec District & "chocolate flint" & MOR1 & 17.74 & 8.06 & 74.19 \\
\hline Tomaszów, Szydłowiec District & "chocolate flint" & TOM1 & 11.84 & 0.00 & 88.16 \\
\hline Polany II, Radom District & "chocolate flint" & POL1 & 50.59 & 26.49 & 22.93 \\
\hline Seredzice, Radom District & "chocolate flint" & SER24-B1 & 10.00 & 5.00 & 85.00 \\
\hline Seredzice, Radom District & "chocolate flint" & SER24-B2 & 4.55 & 4.55 & 90.91 \\
\hline Seredzice "Hapki", Radom District & "chocolate flint" & HAB1 & 8.70 & 6.52 & 84.78 \\
\hline Iłża, Radom District & "chocolate flint" & IL2-SCH & 14.81 & 18.52 & 66.67 \\
\hline Błaziny Górne, Radom District & "chocolate flint" & BLG-CZK1 & 11.63 & 8.84 & 79.53 \\
\hline Seredzice, Radom District & striped flint & PSP-24BU1 & 7.32 & 2.44 & 90.24 \\
\hline Błaziny Górne, Radom District & striped flint & BLGPSP-1 & 25.00 & 12.50 & 62.50 \\
\hline $\begin{array}{l}\text { Krzemionki Opatowskie, Ostrowiec Świętokrzyski } \\
\text { District }\end{array}$ & striped flint & KO-GS1 & 13.79 & 1.72 & 84.48 \\
\hline $\begin{array}{l}\text { Krzemionki Opatowskie, Ostrowiec Świętokrzyski } \\
\text { District }\end{array}$ & striped flint & KO-GS2 & 3.72 & 87.19 & 9.09 \\
\hline Borownia, Ostrowiec Świętokrzyski District & striped flint & BOB?2 & 11.24 & 2.25 & 86.52 \\
\hline Borownia, Ostrowiec Świętokrzyski District & striped flint & BOB1 & 64.29 & 34.87 & 0.84 \\
\hline Świeciechów Lasek, Kraśnik District & $\begin{array}{l}\text { gray white-spotted } \\
\text { flint }\end{array}$ & SWLAS-1 & 5.88 & 5.88 & 88.24 \\
\hline
\end{tabular}

Table 1. Percentage of aliphatic, aromatic and polar fractions for the exemplary attempts of analyze samples of siliceous rocks (see Fig. 3). //

1. táblázat. Alifás, aromás és poláris frakciók megoszlása a kovás kőzetminták próbaméréseinél (ld. 3. ábra). 


\begin{tabular}{|c|c|}
\hline Symbol & Name \\
\hline C20 & C20-tricyclic triterpene \\
\hline C21 & C21-tricyclic triterpene \\
\hline C22 & C22-tricyclic triterpene \\
\hline $\mathrm{C} 23$ & C23-tricyclic triterpene \\
\hline C24 & C24-tricyclic triterpene \\
\hline C25 & C25-tricyclic triterpene \\
\hline C26 & C26-tricyclic triterpene \\
\hline $\mathrm{C} 27$ & C27-tricyclic triterpene \\
\hline C28 & C28-tricyclic triterpene \\
\hline C29 & C29-tricyclic triterpene \\
\hline Ts & $18 \alpha(H)-22,29,30$-trisnorneohopan \\
\hline Tm & $17 \alpha(H)-22,29,30$-trisnorhopan \\
\hline$C 29 \alpha \beta$ & C29-17 $\alpha, 21 \beta-30$-norhopan \\
\hline$C 29 \beta \alpha$ & C29-17ß21 $\alpha$-hopan \\
\hline$C 30 \alpha \beta$ & C30-17 $\alpha 21 \beta$-hopan \\
\hline $\mathrm{C} 30 \beta \alpha$ & 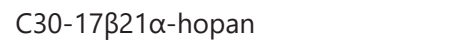 \\
\hline C31 $\alpha \beta 22 S$ & C31-17 $\alpha, 21 \beta-29-$ homohopan $22 S$ \\
\hline$C 31 \alpha \beta 22 R$ & C31-17 $\alpha, 21 \beta-29-$ homohopan 22R \\
\hline C32 $\alpha \beta 225$ & 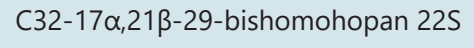 \\
\hline$C 32 \alpha \beta 22 R$ & C32-17 $\alpha, 21 \beta-29$-bishomohopan 22R \\
\hline$C 33 \alpha \beta 225$ & C33-17 $\alpha, 21 \beta-29$-trishomohopan 22S \\
\hline$C 33 \alpha \beta 22 R$ & C33-17 $\alpha, 21 \beta-29$-trishomohopan 22R \\
\hline
\end{tabular}

Table 2. Explanation of compounds name used for tri- and pentacyclic triterpenoids (see Fig. 6 and 7). //

2. táblázat. A tri- és pentaciklikus triterpenoidokra használt jelölések magyarázata (ld. 6-7. ábra).

\begin{tabular}{|c|c|}
\hline Name & Symbol \\
\hline 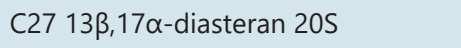 & $C 27 \beta \alpha 20 S$ \\
\hline 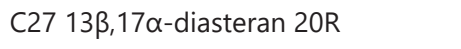 & $C 27 \beta \alpha 20 R$ \\
\hline C27 13 $\alpha, 17 \beta$-diasteran $20 \mathrm{~S}$ & $C 27 \alpha \beta 20 S$ \\
\hline C27 13 $\alpha, 17 \beta$-diasteran 20R & $C 27 \alpha \beta 20 R$ \\
\hline C28 $13 \beta, 17 \alpha$-diasteran $20 \mathrm{~S}(24 \mathrm{~S}+\mathrm{R})$ & $C 28 \beta \alpha 20 S(24 S+R)$ \\
\hline C28 $13 \beta, 17 \alpha$-diasteran $20 \mathrm{R}(24 \mathrm{~S}+\mathrm{R})$ & $C 28 \beta \alpha(24 S+R)$ \\
\hline C27 $5 \alpha, 14 \alpha, 17 \alpha$-steran $20 S$ & C27 $\alpha \alpha \alpha 20 S$ \\
\hline C28 13 $\alpha, 17 \beta$-diasteran $20 \mathrm{~S}$ & $C 28 \alpha \beta 20 S$ \\
\hline C27 $5 \alpha, 14 \beta, 17 \beta$-steran $20 \mathrm{R}$ & $C 27 \alpha \beta \beta 20 R$ \\
\hline 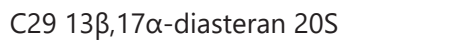 & $C 29 \beta \alpha 20 S$ \\
\hline C27 $5 \alpha, 14 \beta, 17 \beta$-steran $20 S$ & $\mathrm{C} 27 \alpha \beta \beta 20 \mathrm{~S}$ \\
\hline C27 $5 \alpha, 14 \alpha, 17 \alpha$-steran $20 \mathrm{R}$ & $\mathrm{C} 27 \alpha \alpha \alpha 20 \mathrm{R}$ \\
\hline C29 $13 \beta, 17 \alpha$-diasteran $20 \mathrm{~S}$ & $C 29 \beta \alpha 20 S$ \\
\hline C29 $13 \beta, 17 \alpha$-diasteran 20R & $C 29 \beta \alpha 20 R$ \\
\hline C28 $5 \alpha, 14 \alpha, 17 \alpha$-steran $20 S$ & C28 $\alpha \alpha \alpha 20 S$ \\
\hline C28 $5 \alpha, 14 \beta, 17 \beta$-steran $20 \mathrm{R}$ & $C 28 \alpha \beta \beta 20 R$ \\
\hline C28 $5 \alpha, 14 \beta, 17 \beta$-steran $20 S$ & $C 28 \alpha \beta \beta 20 S$ \\
\hline 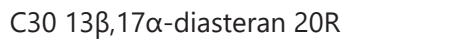 & $C 30 \beta \alpha 20 R$ \\
\hline C29 $13 \alpha, 17 \beta$-diasteran $20 \mathrm{R}$ is & $C 29 \alpha \beta 20 R$ is \\
\hline C28 $5 \alpha, 14 \alpha, 17 \alpha$-steran $20 \mathrm{R}$ & $\mathrm{C} 28 \alpha \alpha \alpha 20 \mathrm{R}$ \\
\hline C29 $5 \alpha, 14 \alpha, 17 \alpha$-steran $20 \mathrm{~S}$ & C29 $\alpha \alpha \alpha 20 S$ \\
\hline C29 $5 \alpha, 14 \beta, 17 \beta$-steran $20 \mathrm{R}$ & $C 29 \alpha \beta \beta 20 R$ \\
\hline C29 $5 \alpha, 14 \beta, 17 \beta$-steran $20 \mathrm{~S}$ & $C 29 \alpha \beta \beta 20 S$ \\
\hline C29 $5 \alpha, 14 \alpha, 17 \alpha$-steran 20R & $\mathrm{C} 29 \alpha \alpha \alpha 20 \mathrm{R}$ \\
\hline C30 $5 \alpha, 14 \beta, 17 \beta$-steran $20 \mathrm{R}+\mathrm{S}$ & $C 30 \alpha \beta \beta 20 R+S$ \\
\hline C30 5 $\alpha, 14 \alpha, 17 \alpha$-steran 20R & $\mathrm{C} 30 \alpha \alpha \alpha 20 \mathrm{R}$ \\
\hline
\end{tabular}

Table 3. Explanation of compounds name used for steranes and diasterans (see Fig. 6 and 7). //

3. táblázat. A szteránokra és diaszteránokra használt jelölések magyarázata (ld. 6-7. ábra). 


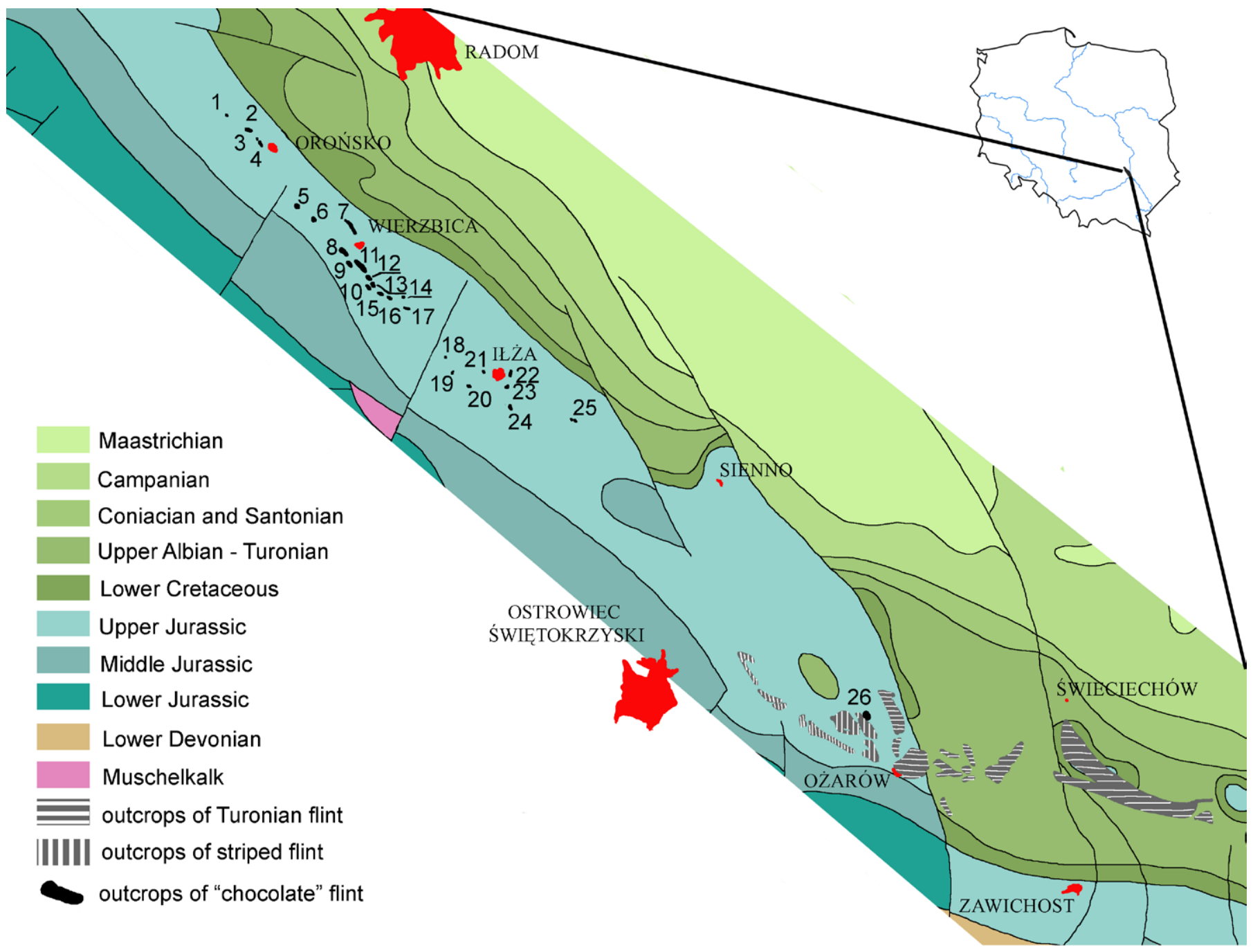

Figure 2. Occurrence of "chocolate" flint in pre-Quaternary formations on the northeastern outskirts of the Holy Cross Mountains. 1 - ChronówKolonia, Szydłowiec District; 2 - Guzów Szydłowiec District; 3 - Orońsko "Mały Orońsk" Szydłowiec District; 4 - Orońsko (Orońsk II) Szydłowiec District; 5 - Tomaszów Szydłowiec District; 6 - Rzeczków, Radom District; 7 - Wierzbica quarry, Radom District; 8 - Wierzbica "Zele", Radom District; 9 - Wierzbica "Krzemienica", Radom District; 10 - Polany kolonie IV, Radom District; 11 - Polany kolonie I, Radom District; 12 - Polany kolonie II, Radom District; 13 - Polany kolonie Ila, Radom District; 14 - Polany III, Radom District; 15 - Polany kolonie III, Radom District; 16 - Polany I, Radom District; 17 - Polany II, Radom District; 18 - Pakosław, Radom District; 19 - Seredzice, Radom District; 20 - Seredzice "Kolonia", Radom District; 21 - Iłża "Wąwóz Żuchowiec", Radom District; 22 - Iłża "Krzemieniec" II, Radom District; 23 - Hłża "Krzemieniec" I, Radom District; 24 - Błaziny Górne, Radom District; 25 - Prędocin, Radom District; 26 - Gliniany "Wzgórze Kruk", Opatów District (Schild 1971, 1976; Balcer 1976; Dadlez et al. 2000; Budziszewski 2008; Budziszewski et al. 2015). //

2. ábra. "Csokoládé" kova előfordulások a Szentkereszt-hegység északkeleti peremeinek negyedidőszak előtti formációiban. 1 - Chronów-Kolonia, Szydłowiec körzet; 2 - Guzów Szydłowiec körzet; 3 - Orońsko "Mały Orońsk" Szydłowiec körzet; 4 - Orońsko (Orońsk II) Szydłowiec körzet; 5 Tomaszów Szydłowiec körzet; $\mathbf{6}$ - Rzeczków, Radom körzet; 7 - Wierzbica quarry, Radom körzet; 8 - Wierzbica "Zele", Radom körzet; 9 - Wierzbica "Krzemienica", Radom körzet; 10 - Polany kolonie IV, Radom körzet; 11 - Polany kolonie I, Radom körzet; 12 - Polany kolonie II, Radom körzet; 13 - Polany kolonie Ila, Radom körzet; 14 - Polany III, Radom körzet; 15 - Polany kolonie III, Radom körzet; 16 - Polany I, Radom körzet; 17 - Polany II, Radom körzet; 18 - Pakosław, Radom körzet; 19 - Seredzice, Radom körzet; 20 - Seredzice "Kolonia", Radom körzet; 21 - Hża "Wąwóz Żuchowiec", Radom körzet; 22 - Iłża "Krzemieniec" II, Radom körzet; 23 - Iłża "Krzemieniec" I, Radom körzet; 24 - Błaziny Górne, Radom körzet; 25 - Prędocin, Radom körzet; 26 - Gliniany "Wzgórze Kruk", Opatów körzet (Schild 1971, 1976; Balcer 1976; Dadlez et al. 2000; Budziszewski 2008; Budziszewski et al. 2015). 


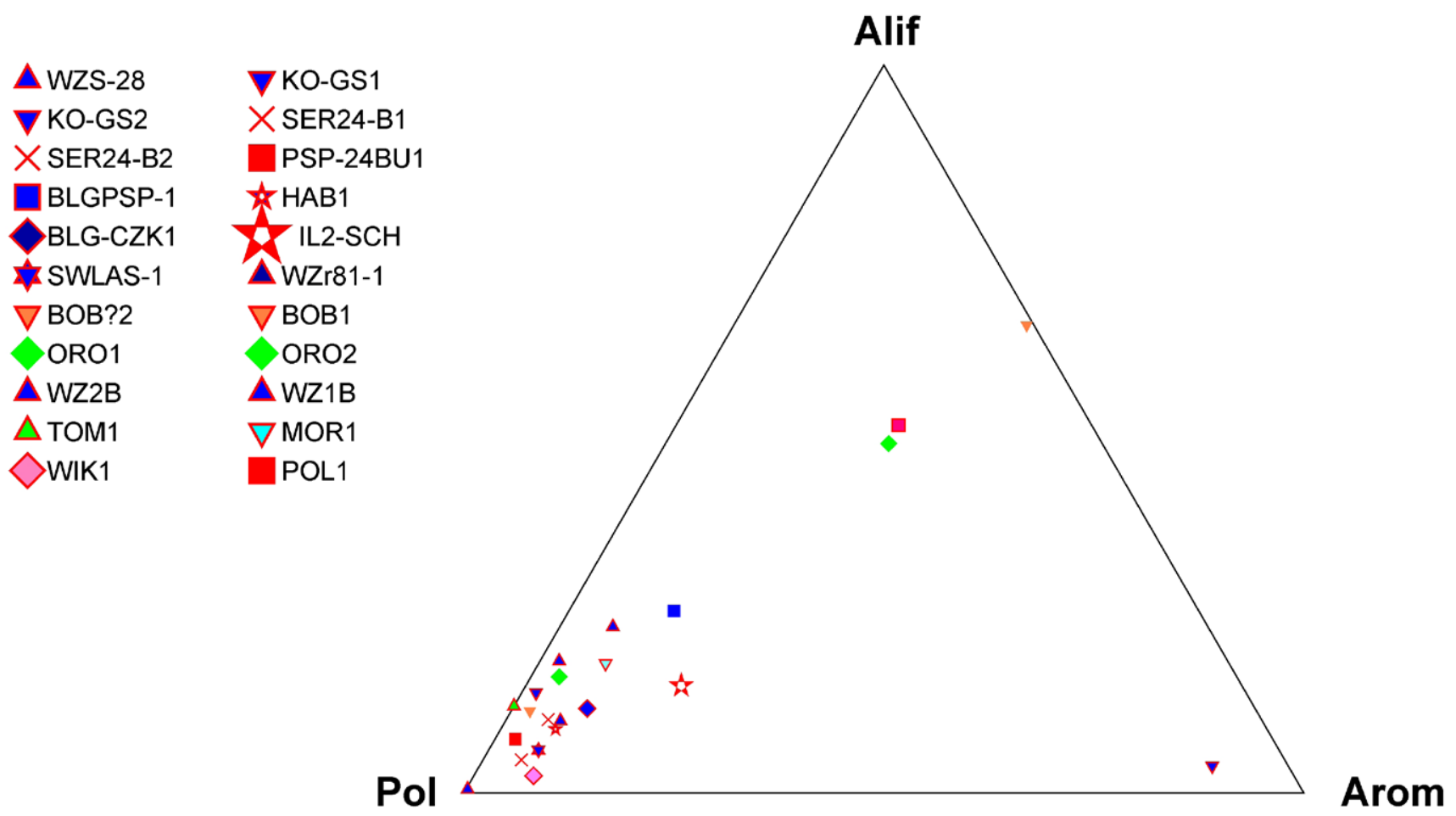

Figure 3. Ternary diagram showing the percentage of each fraction in the extract from the analyzed flint. 100\% of the fraction in the corners (Pol polar, Aliph - aliphatic, Arom - aromatic fractions; see Table 1). //

3. ábra. Háromszögdiagram a frakciók megoszlásával a kovamintákban. 100\% a sarkokban (Pol - poláris; Aliph - alifás; Arom - aromás frakciók; ld. 1. Táblázat).

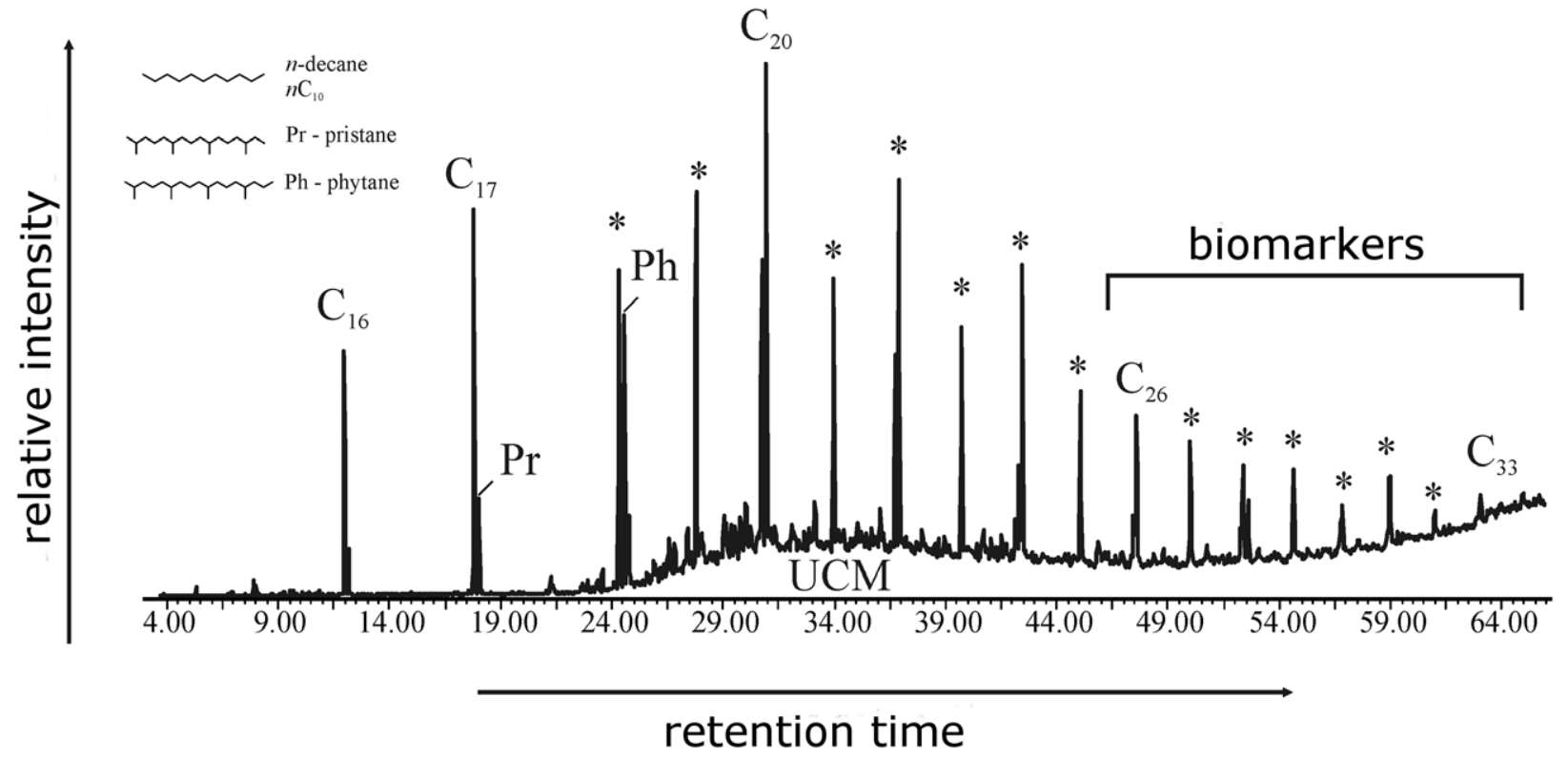

Figure 4. Total ion chromatogram (TIC) of aliphatic fraction. //

4. ábra. Az alifás frakció teljes ion kromatogramja (TIC). 


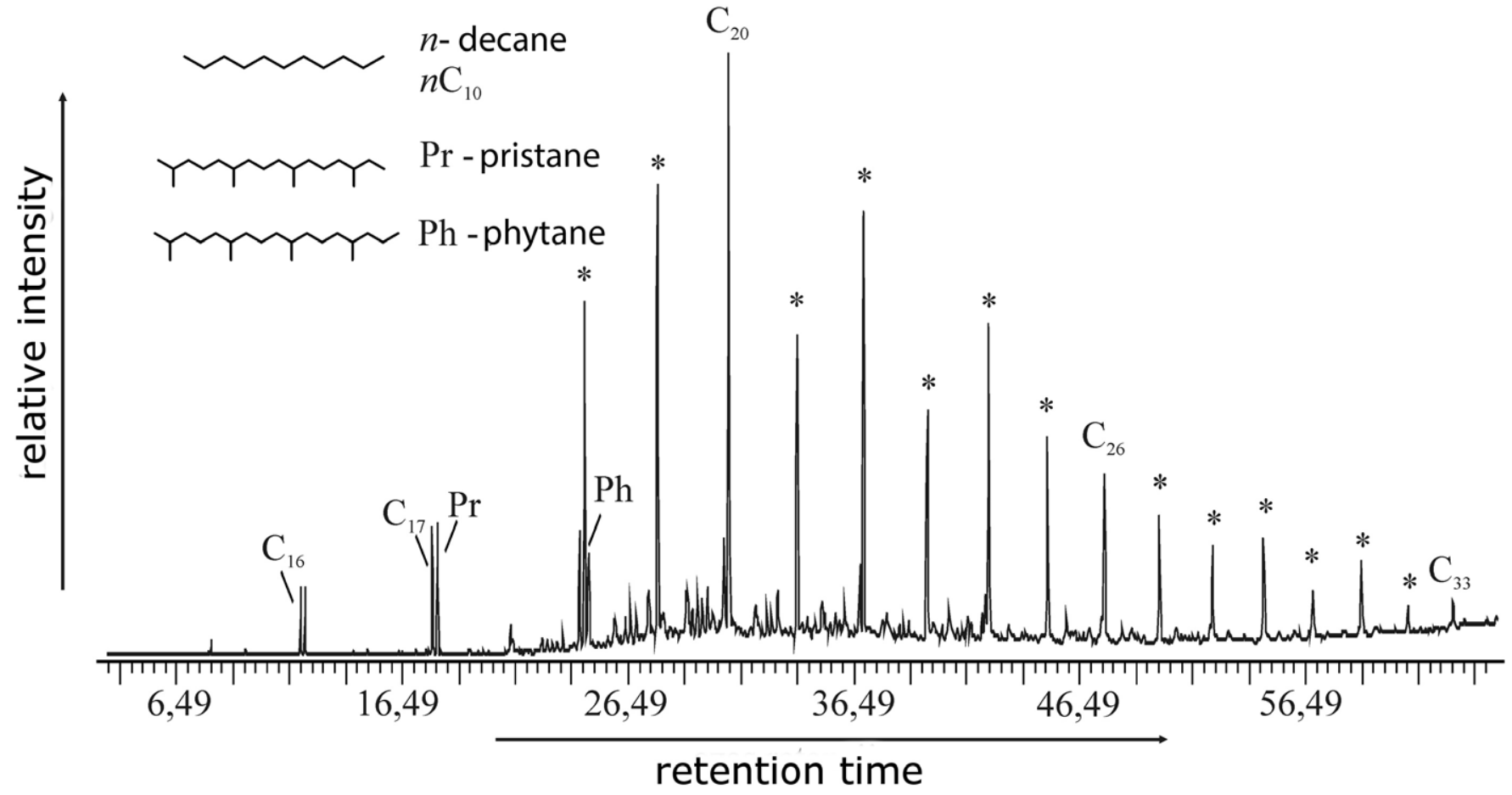

Figure 5. Distribution of $n$-alkane and isoprenoids $(m / z=71) . C_{16}-n$-hepthadecane, $\operatorname{Pr}$ - pristane, $\mathrm{Ph}$ - phytane, * $-n$-alkanes. // 5. ábra. $n$-alkánok és izoprenoidok eloszlása $(m / z=71) . C_{16}-n$-heptadekán, $\operatorname{Pr}$ - prisztán, $\mathrm{Ph}$ - fitán, * $-n$-alkánok. 

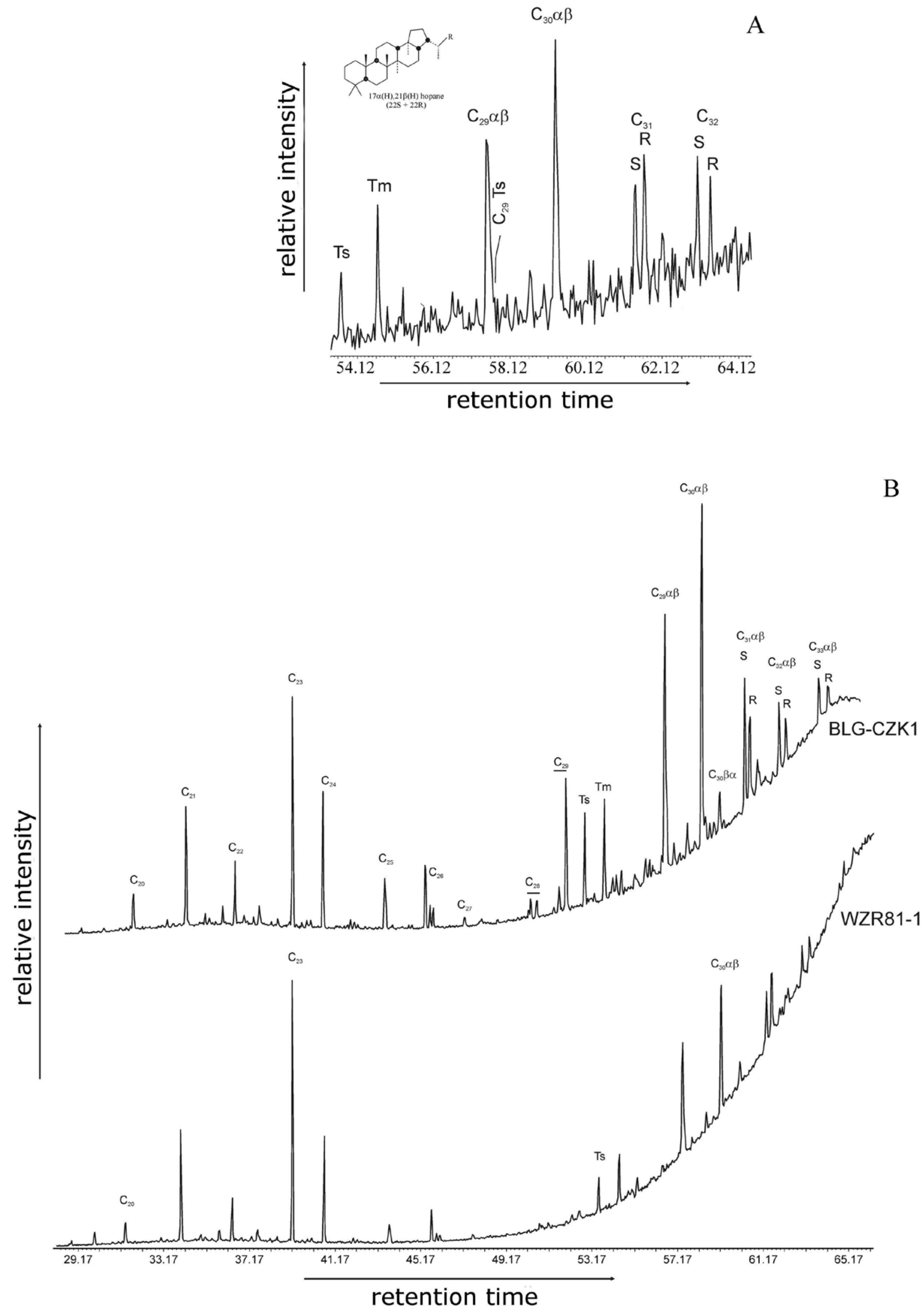

Figure 6. Fragmentograms with distributions $(A)$ and comparsion of distributions of pentacyclic triterpenoids $(m / z=191)$ between flints from Wierzbica "Zele" and Błaziny Górne (see Table 2 and 3 for identification). //

6. ábra. Fragmentogramok a pentaciklikus triterpenoidok $(m / z=191)$ eloszlásával $(A)$ és azok összehasonlításával (B) a Wierzbica „Zele” és a Błaziny Górne forrásokból származó tűzkövek esetében (a jelmagyarázatot lásd a 2. és 3. táblázatban). 


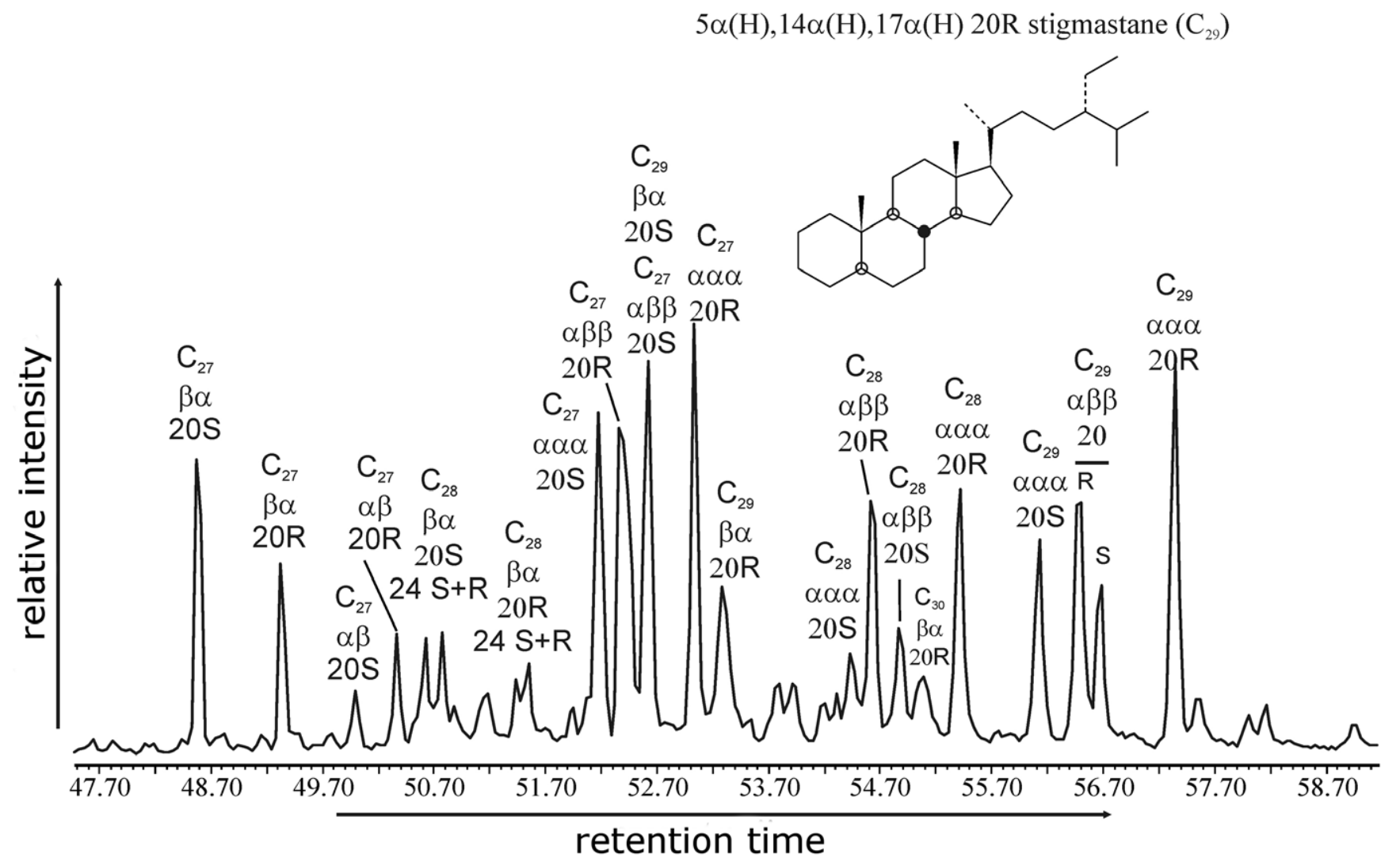

Figure 7. Steranes and diasterans $(m / z=217+259)$ distribution for a flint from outcrop in Błaziny Górne (identification of shortcuts in Table 2 and 3). //

7. ábra. Szteránok és diaszteránok $(m / z=217+259)$ eloszlása egy, a Błaziny Górne forrásból származó tűzkő esetében ( $a$ rövidítések feloldása a 2. és 3. táblázatban). 